\title{
Expression of neuromedins $S$ and $U$ and their receptors in the hypothalamus and endocrine glands of the rat
}

\author{
MARCIN RUCINSKI ${ }^{1}$, AGNIESZKA ZIOLKOWSKA ${ }^{1}$, GIULIANO NERI ${ }^{2}$, \\ MARCIN TREJTER ${ }^{1}$, TOMASZ ZEMLEDUCH ${ }^{1}$, MARIANNA TYCZEWSKA ${ }^{1}$, \\ GASTONE G. NUSSDORFER ${ }^{2}$ and LUDWIK K. MALENDOWICZ ${ }^{1}$ \\ ${ }^{1}$ Department of Histology and Embryology, Poznan School of Medicine, Poznan PL-69781, Poland;
}

Received March 14, 2007; Accepted April 20, 2007

\begin{abstract}
Neuromedin S (NMS) and neuromedin U (NMU) are regulatory peptides that share the C-terminal amino-acid sequence and act via common $\mathrm{G}$ protein-coupled receptors called NMUR1 and NMUR2. Semiquantitative real time-PCR showed that in the rat hypothalamus and testis NMS gene expression was markedly higher than that of the NMU gene, while the reverse occurred in the anterior pituitary and thyroid gland. Low expression of both genes was detected in the thymus, adrenal gland and ovary, whereas in the pancreatic islets only the expression of NMU mRNA was detected. In the rat hypothalamus the expression of the NMUR2 gene was strikingly higher than that of the NMUR1 gene; in contrast, in the testis and ovary the very low expression of NMUR2 contrasted with the relatively high expression of the NMUR1 gene. In the other glands examined only expression of the NMUR1 gene was found. The marked differences in the level of expression of NMU, NMS and their receptors in the hypothalamus and endocrine glands of the rat suggest that in this species such neuromedins may play different roles in the functional regulation of neuroendocrine axes.
\end{abstract}

\section{Introduction}

Neuromedin S (NMS) is a 30 -amino acid peptide, which has been recently isolated from the human, rat and mouse brain as an endogenous ligand of the orphan $\mathrm{G}$ protein-coupled receptors FM-3/GPR66 and FM-4/TGR-1 that in turn have been identified as neuromedin $\mathrm{U}$ (NMU) receptors (NMUR) 1 and 2, respectively (1-6). This neuropeptide shares with NMU the C-terminal amino-acid sequence, and was named

Correspondence to: Professor G.G. Nussdorfer, Department of Human Anatomy and Physiology, Section of Anatomy, Via Gabelli 65, I-35121 Padua, Italy

E-mail: gastone.nusdorfer@unipd.it

Key words: neuromedin S, neuromedin U, neuromedin-U receptors, hypothalamus, endocrine glands, rat
NMS because it is highly expressed in the hypothalamic suprachiasmatic nucleus (7-9).

Available findings stress numerous differences between NMS and NMU. NMS is a neuropeptide mainly involved in the modulation of the immune response, regulation of circadian rhythms and spermatogenesis. Moreover, NMS has been also suggested to be a potent anorexigenic hormone that acts, among others, via CRH neurons (7-9). NMU is a brain-gut peptide involved in the regulation of energy homeostasis and neuroendocrine functions $(4,5,10-18)$.

The aim of the present study was to compare by semiquantitative real-time reverse transcription (RT)-polymerase chain reaction (PCR) the level of expression of NMS, NMU, NMUR1 and NMUR2 genes in the hypothalamus and endocrine glands of the rat.

\section{Materials and methods}

Animals. Adult male and female Wistar rats (200-250 g body weight) were kept under a 14:10-h light-dark cycle (illumination onset at 8:00 a.m.) at $23^{\circ} \mathrm{C}$, and maintained on a standard diet and tap water ad libitum. Rats were decapitated, and the hypothalamus, anterior pituitary, thyroid gland, thymus, pancreas, adrenal glands, ovaries and testes were promptly removed and placed in RNA later (Qiagen, Hilden, Germany) (19). Pancreatic islets were isolated by collagenase digestion (20). The study protocol was approved by the local Ethics Committees for Biomedical Studies.

$R T-P C R$. Total RNA was extracted from $30 \mathrm{mg}$ of tissues, and reverse transcribed to cDNA (21-23). Conventional PCR was performed as previously described (24-26), using the following program: predenaturation step at $94^{\circ} \mathrm{C}$ for $10 \mathrm{~min}$ to activate Taq DNA polymerase, followed by 35 cycles of denaturation at $94^{\circ} \mathrm{C}$ for $30 \mathrm{sec}$, annealing at $58^{\circ} \mathrm{C}$ for $60 \mathrm{sec}$ and extension at $68^{\circ} \mathrm{C}$ for $120 \mathrm{sec}$. Primer sequences and the predicted sizes of amplicons were as follows: i) NMS, sense (276-293) 5'-AGTTTGCTCCCGTCCACT-3' and antisense (444-465) 5'-TTGTCAGTGTATCTTCCATTCC-3' (190 bp; NM012233); ii) NMU, sense (50-69) 5'-GCTTTAACACCC GCACAACA-3' and antisense (346-365) 5'-GGCAAAGCTT CCTCAATGCA-3' (316 bp; NM022239); iii) NMUR1, sense (481-500) 5'-GCCATCTGGGTCTTCGCTAT-3' and antisense 

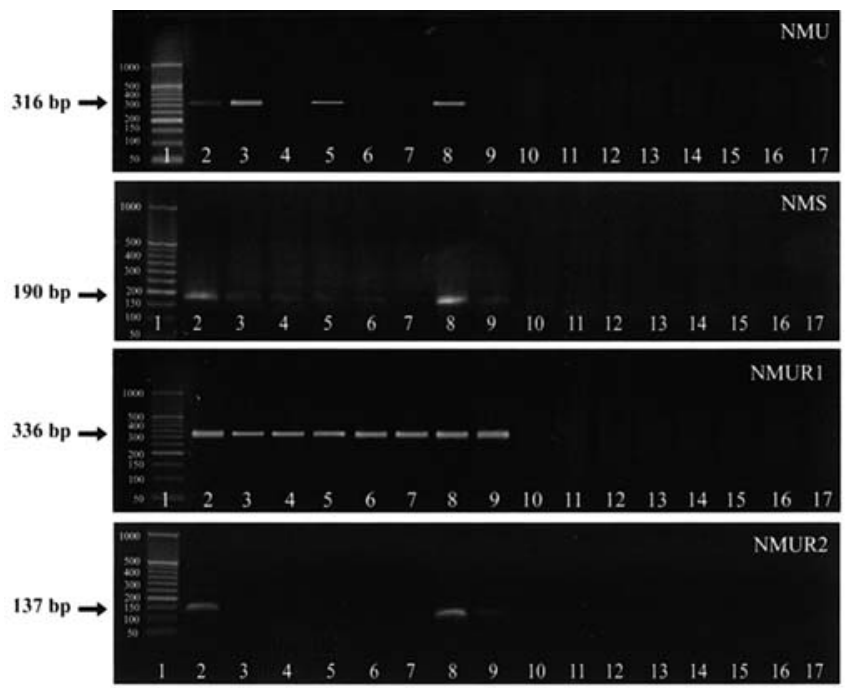

Figure 1. Ethidium bromide-stained $2 \%$ agarose gel showing cDNA amplified with rat NMU, NMS, NMUR1 and NMUR2 specific primers from exemplary rat hypothalamus (2), anterior pituitary (3), adrenal gland (4), thyroid gland (5), thymus (6), pancreatic islets (7), testis (8) and ovary (9). Respective negative controls (no RT of the RNA) are shown in lanes 10-16. Lane 1 was loaded with $200 \mathrm{ng}$ of a DNA size marker (50 bp DNA Ladder; MBI Fermentas, Vilnius, Lithuania).

(797-816) 5'-CACCTGTCTGCGTTCCCTAT-3' (336 bp; AF242873); and iv) NMUR2, sense (841-859) 5'-GAATCCC TTGAGGCGAACA-3' and antisense (958-977) 5'-CTGAAG AAGAGCCGGTCCAC-3' (137 bp; NM022275). To rule out the possibility of amplifying genomic DNA, one PCR was performed without prior RT of the RNA. Detection of the PCR amplification products was performed by size fractionation on $2 \%$ agarose gel electrophoresis. The specificity of the PCR was further verified by sequencing analysis (27).

Real-time PCR. Semiquantitative real-time PCR was carried out in a Roche Light Cycler 2.0 (Roche Applied Science, Basel, Switzerland) with software version 4.0 (28-31), using the following program: predenaturation step at $95^{\circ} \mathrm{C}$ for $10 \mathrm{~min}$, and 45 cycles of three-step amplification (denaturation, $95^{\circ} \mathrm{C}$ for $10 \mathrm{sec}$; annealing, $58^{\circ} \mathrm{C}$ for $5 \mathrm{sec}$; and extension, $72^{\circ} \mathrm{C}$ for $10 \mathrm{sec})$. Subsequently, melting curve $\left(60-90^{\circ} \mathrm{C}\right.$ with a heating rate of $0.1^{\circ} \mathrm{C} / \mathrm{sec}$ ) was performed to check the specificity of amplification and the presence of byproducts. All samples were amplified in duplicate, and the hypoxanthine guanine phosphoribosyl transferase 1 (HPRT) gene was used as a reference to normalize data. The primer sequences were as follows: i) NMS, see conventional PCR; ii) NMU, sense (50-69) 5'-GCTTTAACACCCGCACAACA-3' and antisense (230-249) 5'-TGAGGCGATATTGGCGTACC-3' (200 bp; NM022239); iii) NMUR1, sense (1-20) 5'-ATGCTCTCCC CAAATGCTTC-3' and antisense (172-190) 5'-CCAGAGT GCCCACTACGAA-3' (190 bp; NM023100); iv) NMUR2, see conventional PCR; and v) HPRT, sense (391-412) 5'CAGTCAACGGGGGACATAAAAG-3' and antisense (515536) 5'-ATTTTGGGGCTGTACTGCTTGA-3' (146 bp; NM012583).

Western blotting. Prepro-NMS protein was identified in the rat hypothalamus and testis. Samples were homogenized in
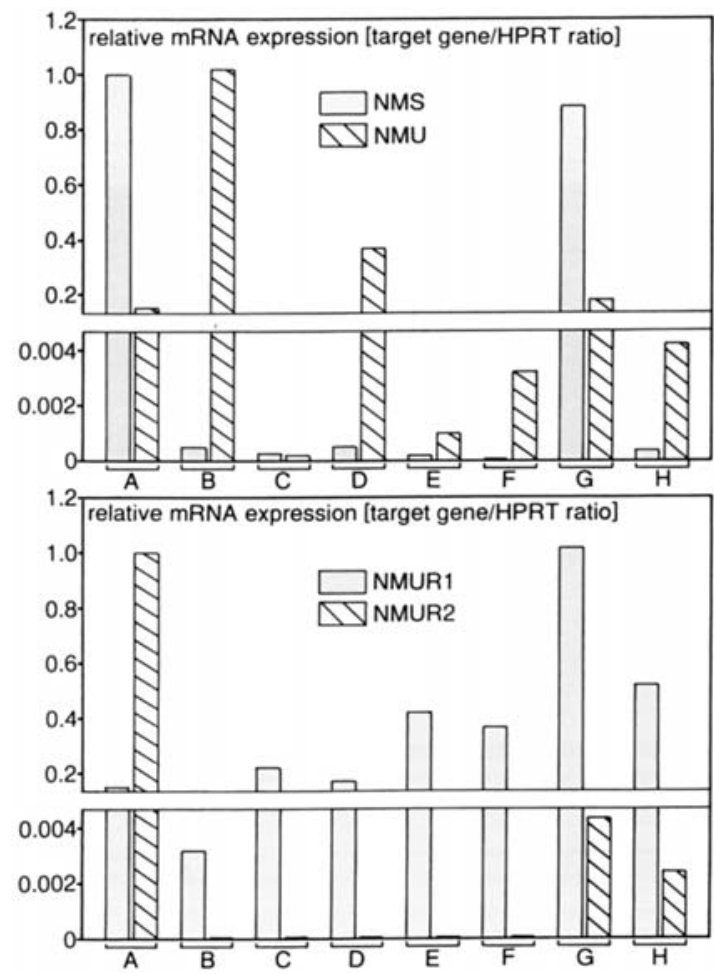

Figure 2. Real-time PCR semiquantitative analysis of NMU, NMS (upper panel), NMUR1 and NMUR2 gene expression (lower panel) in the hypothalamus (A), anterior pituitary (B), adrenal gland (C), thyroid gland (D), thymus $(\mathrm{E})$, pancreatic islets $(\mathrm{F})$, testis $(\mathrm{G})$ and ovary $(\mathrm{H})$ of the adult rat. Bars are means of two independent estimations.

Tris-sucrose-EDTA buffer $(10 \mathrm{mM}$ Tris, $250 \mathrm{mM}$ sucrose and $0.1 \mathrm{mM}$ EDTA; pH 7.4), and centrifuged at $600 \mathrm{x} \mathrm{g}$ for $30 \mathrm{~min}$ at $4^{\circ} \mathrm{C}$ to remove cell debris. Protein concentration was determined by the Bradford method. Samples of $20 \mu \mathrm{g}$ of protein were loaded into each lane, separated on a $15 \%$ SDS-polyacrylamide electrophoretic gel, and then transferred onto a PVDF membrane (Millipore, Bedford, MA). Transferred proteins were stained with Ponceau S, and non-specific binding was blocked by immersing the membrane in $5 \%$ bovine serum albumine at $4^{\circ} \mathrm{C}$ overnight. Membranes were incubated with rabbit anti-NMS primary antibody (Phoenix Pharmaceuticals, Belmont, CA) $\left(1: 2,000\right.$ dilution) for $60 \mathrm{~min}$ at $37^{\circ} \mathrm{C}$. Then, after washing in TBST [10 mM Tris ( $\mathrm{pH} 8.0), 150 \mathrm{mM} \mathrm{NaCl}$ and $0.05 \%$ Tween-20] three times for $10 \mathrm{~min}$, membranes were incubated with anti-rabbit IgG peroxidase-conjugated secondary antibody (Sigma-Aldrich Corporation, St. Louis, MO) (1:10,000 dilution) for $60 \mathrm{~min}$ at room temperature. Membranes were washed four times in TBST, and the target protein was detected by an ECL advanced Western blotting detection kit (Amersham, Aylesbury, UK). Chemiluminescence signal was then transferred on a CL-X Posure Film (Pierce Biotechnology, Rockford, IL).

\section{Results}

Conventional PCR detected the presence of NMU mRNA in the anterior pituitary, thyroid gland and testis of the adult rat, and of NMS mRNA in the hypothalamus and testis. NMUR1 mRNA was present in all tissues examined, while NMUR2 mRNA was found only in the hypothalamus and testis (Fig. 1). 


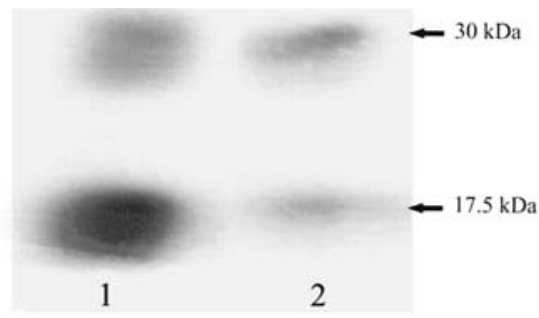

Figure 3. Western blotting of prepro-NMS in the hypothalamus (1) and testis (2) of the adult rat.

Real-time PCR revealed that in the rat hypothalamus and testis NMS gene expression was from 2- to 3-fold higher than that of the NMU gene, while in the anterior pituitary and thyroid gland expression of the NMU gene was nearly 1000 times higher than that of the NMS gene. Low expression of both NMU and NMS genes was observed in the thymus, adrenal gland and ovary, while in pancreatic islets only NMU expression was detected (Fig. 2, upper panel). In the hypothalamus expression of the NMUR2 gene was approximately 10 times higher than that of the NMUR1 gene, whereas in the testis and ovary very low expression of the NMUR2 gene contrasted with a relatively high expression of the NMUR1 gene. In the anterior pituitary, thyroid gland, thymus, pancreatic islets and adrenal gland only expression of the NMUR1 gene was detected (Fig. 2, lower panel).

Western blotting showed the expected NMS-protein sizeband of $17.5 \mathrm{kDa}$ in the hypothalamus and testis. An additional band of approximately $30 \mathrm{kDa}$ was also observed (Fig. 3).

\section{Discussion}

Earlier studies revealed the presence of NMU-like immunoreactivity in the central nervous system and alimentary tract, as well as in the excretory, respiratory, endocrine and immune systems. The NMU protein expression was very intense in the hypothalamus, thalamus, anterior pituitary and thyroid gland (32-42). In the hypothalamus, NMU-positive nerve fibers were observed in the supraoptic and paraventricular nuclei, while NMU-positive perikarya were restricted to the rostrocaudal part of the arcuate nucleus (34-36). However, in situ hybridization demonstrated the presence of NMU mRNA in the tuberal part of the hypothalamus, but not in the arcuate nucleus (40). On the other hand, the NMS gene was found to be specifically expressed only in the hypothalamic suprachiasmatic nucleus, as well as in the rat testis (8). Our study confirms the expression of NMS as mRNA and protein in the rat hypothalamus and testis. However, Western blotting revealed two bands, one with a molecular weight typical for prepro-NMS protein $(17.5 \mathrm{kDa})$ and one of approximately $30 \mathrm{kDa}$. Similar bands for hypothalamic NMS protein are also shown in the manual for applied methods of Phoenix Pharmaceuticals, and it remains to be established whether the higher molecular weight band corresponds to a prepro-NMS protein dimer. In contrast with previous studies, NMU mRNA expression was not detected in the rat hypothalamus, and this negative results requires further investigation.

Both NMU and NMS interact with specific NMUR1 and NMUR2 (8), the former being the peripheral receptor and the latter the central one (43-44). Accordingly, the widespread distribution of the NMUR1 gene, among others in several endocrine glands, has been consistently reported $(2,4,6,43,45,46)$, while the presence of the NMUR2 gene was restricted to different brain regions, including numerous hypothalamic nuclei $(4,43,45,47)$, and rat testis $(43,46,47)$. Our present findings confirm this distribution of NMUR1 and NMUR2. They also show the expression of NMUR2 in the rat ovary, at a level comparable to that in the testis but markedly lower than that of the NMUR1 gene.

As far as the physiological role of NMU and NMS is concerned, experimental data suggest their involvement in the regulation of neuroendocrine axes, including the gonadotropic one $(7-18,48,49)$. Our semiquantitative real-time PCR data indicate great differences in the level of expression of these neuromedins and their receptors in the endocrine glands, thereby suggesting that NMU and NMS may play different roles in the functional regulation of the endocrine system. It is believed that such neuromedins, and especially NMS, exert their biological effects mainly via autocrine-paracrine mechanisms (8). However, Phoenix Pharmaceuticals has recently made available kits for NMU and NMS assay in the human, rat and mouse serum that showed that NMS concentration may reach values of approximately $30 \mathrm{pg} / \mathrm{ml}$ in humans. This finding makes it reasonable to suggest that NMU and NMS may modulate neuroendocrine axes by also acting as true circulating hormones.

\section{Acknowledgments}

We are indebted to Miss A. Coi for outstanding secretarial support and help in the search and delivery of bibliographic items. This manuscript is a part of the $\mathrm{Ph}$. D. thesis of Marcin Trejter submitted to the Poznan School of Medicine.

\section{References}

1. Tan CP, McKee KK, Liu QY, Palyha OC, Feighner SD, Hreniuk DL, Smith RG and Howard AD: Cloning and characterization of a human and murine T-cell orphan G-proteincoupled receptor similar to the growth hormone secretagogue and neurotensin receptors. Genomics 52: 223-229, 1998.

2. Fujii R, Hosoya M, Fukusami S, Kazamata Y, Habata Y Hinuma S, Onda H, Nishimura $\mathrm{O}$ and Fujino M: Identification of neuromedin $\mathrm{U}$ as the cognate ligand of the orphan $\mathrm{G}$ proteincoupled receptor FM-3. J Biol Chem 275: 21068-21074, 2000.

3. Howard AD, Wang R, Pong SS, Mellin TN, Strack A, Guan XM, Zeng Z, Williams DL Jr, Feighner SD, Nunes CN, Murphy B, Stair JN, Yu H, Jiang Q, Clements MK, Tan CP, McKee KK, Hreniuk DL, McDonald TP, Lynch KR, Evans JF, Austin CP, Caskey CT, Van der Ploeg LH and Liu Q: Identification of receptors for neuromedin $U$ and its role in feeding. Nature 406: 70-74, 2000.

4. Kojima M, Maruno R, Nakazato M, Date Y, Murakami N, Hanada R, Matsuo $\mathrm{H}$ and Kangawa K: Purification and identification of neuromedin $\mathrm{U}$ as an endogenous ligand for an orphan receptor GPR66 (FM3). Biochem Biophys Res Commun 276: 435-438, 2000 .

5. Hedrick JA, Morse K, Shan L, Qiao X, Pang L, Wang S, Laz T, Gustafson EL, Bayne M and Monsma JF: Identification of a human gastrointestinal tract and immune system receptor for the peptide neuromedin U. Mol Pharmacol 58: 870-875, 2000.

6. Szekeres PG, Muir AI, Spinage LD, Miller JE, Butler SI, Smith A, Rennie GL, Murdock PR, Fitzgerald LR, Wu H, McMillan LJ, Guerrera S, Vawter L, Elshourbagy NA, Mooney JL, Bergsma DJ, Wilson $S$ and Chambers JK: Neuromedin $U$ is a potent agonist at the orphan $\mathrm{G}$ protein-coupled receptor FM3. J Biol Chem 275: 20247-20250, 2000. 
7. Ida T, Mori K, Miyazato M, Egi Y, Abe S, Nakahara K, Nishihara M, Kangawa K and Murakami N: Neuromedin S is a novel anorexigenic hormone. Endocrinology 146: 4217-4223, 2005.

8. Mori K, Miyazato M, Ida T, Murakami N, Serino R, Ueta Y, Kojima $\mathrm{M}$ and Kangawa K: Identification of neuromedin $\mathrm{S}$ and possible role in the mammalian circadian oscillator system. EMBO J 24: 325-335, 2005 .

9. Shousha S, Nakahara K, Miyazato M, Kangawa K and Murakami N: Endogenous neuromedin $U$ has anorectic effects in the Japanese quail. Gen Comp Endocrinol 140: 156-163, 2005.

10. Malendowicz LK, Nussdorfer GG, Nowak KW and Mazzocchi G: Effects of neuromedin U-8 on the rat pituitary-adrenocortical axis. In Vivo 7: 419-422, 1993

11. Malendowicz LK: Role of neuromedins in the regulation of adrenocortical function. Horm Metab Res 30: 374-384, 1998.

12. Niimi M, Murao K and Taminato T: Central administration of neuromedin $U$ activates neurons in ventrobasal hypothalamus and brainstem. Endocrine 16: 201-206, 2001.

13. Ozaki Y, Onaka T, Nakazato M, Saito J, Kanemoto K, Matsumoto T and Ueta Y: Centrally administered neuromedin $\mathrm{U}$ activates neurosecretion and induction of C-Fos messenger ribonucleic acid in the paraventricular and supraoptic nuclei of rat. Endocrinology 143: 4320-4329, 2002.

14. Wren AM, Small CJ, Abbott CR, Jethwa PH, Keneddy AR, Murphy KG, Stanley SA, Zollner AN, Ghatei MA and Bloom SR: Hypothalamic actions of neuromedin U. Endocrinology 143: 4227-4234, 2002.

15. Thompson EL, Murphy KG, Todd JF, Martin NM, Small CJ, Ghatei MA and Bloom SR: Chronic administration of NMU into the paraventricular nucleus stimulates the HPA axis but does not influence food intake or body weight. Biochem Biophys Res Commun 323: 65-71, 2004

16. Ueta Y, Ozaki Y and Saito J: Novel G-protein coupled receptor ligands and neurohypophysial hormones. J Neuroendocrinol 16: 378-382, 2004.

17. Jethwa PH, Smith KL, Small CJ, Abbott CR, Darch SJ, Murphy KG, Seth A, Semjonous NM, Pate SR, Todd JF, Ghatei MA and Bloom SR: Neuromedin U partially mediates leptin-induced hypothalamo-pituitary-adrenal (HPA) stimulation and has a physiological role in the regulation of the HPA axis in the rat. Endocrinology 147: 2886-2892, 2006.

18. Novak CM, Zhang M and Levine JA: Neuromedin U in the paraventricular and arcuate hypothalamic nuclei increases non-exercise activity thermogenesis. J Neuroendocrinol 18: 594-601, 2006.

19. Hochól A, Belloni AS, Rucinski M, Ziolkowska A, Di Liddo R, Nussdorfer GG and Malendowicz LK: Expression of neuropeptides $\mathrm{B}$ and $\mathrm{W}$ and their receptors in endocrine glands of the rat. Int J Mol Med 18: 1101-1106, 2006.

20. Lacy PE and Kostianovsky M: Method for the isolation of intact islets of Langerhans from the rat pancreas. Diabetes 16: 35-39, 1967.

21. Albertin G, Carraro G and Nussdorfer GG: Human adrenomedullin gene silencing by short interfering RNAs: a preliminary study. Int J Mol Med 15: 579-583, 2005.

22. Andreis PG, Rucinski M, Neri G, Conconi MT, Petrelli L, Parnigotto PP, Malendowicz LK and Nussdorfer GG: Neuropeptides $\mathrm{B}$ and $\mathrm{W}$ enhance the growth of human adrenocortical carcinoma-derived NCI-H295 cells by exerting MAPK p42/p44mediated proliferogenic and antiapoptotic effects. Int J Mol Med 16: 1021-1028, 2005.

23. Rucinski M, Andreis PG, Ziolkowska A, Nussdorfer GG and Malendowicz LK: Differential expression and function of beacon in the rat adrenal cortex and medulla. Int J Mol Med 16: 35-40, 2005.

24. Albertin G, Carraro G, Petrelli L, Guidolin D, Neri G and Nussdorfer GG: Endothelin-1 and adrenomedullin enhance the growth of human adrenocortical carcinoma-derived SW-13 cell line by stimulating proliferation and inhibiting apoptosis. Int J Mol Med 15: 469-474, 2005.

25. Albertin G, Rucinski M, Carraro G, Forneris M, Andreis PG, Malendowicz LK and Nussdorfer GG: Adrenomedullin and vascular endothelium growth factor genes are overexpressed in the regenerating rat adrenal cortex, and AM and VEGF reciprocally enhance their mRNA expression in cultured rat adrenocortical cells. Int J Mol Med 16: 431-435, 2005.

26. Rucinski M, Albertin G, Spinazzi R, Ziolkowska A, Nussdorfer GG and Malendowicz LK: Cerebellin in the rat adrenal gland: gene expression and effects of CER and [des$\mathrm{Ser}^{1}$ ]CER on the secretion and growth of cultured adrencortical cells. Int J Mol Med 15: 411-415, 2005.
27. Rossi GP, Sticchi D, Giuliani L, Bernante P, Zavattero S, Pessina AC and Nussdorfer GG: Adiponectin receptor expression in the human adrenal cortex and aldosterone-producing adenomas. Int J Mol Med 17: 975-980, 2006.

28. Carraro G, Albertin G, Aragona F, Forneris M, Casale V, Spinazzi R and Nussdorfer GG: Age-dependent decrease in the ghrelin gene expression in the human adrenal cortex: a real time PCR study. Int J Mol Med 17: 319-321, 2006.

29. Rucinski M, Ziolkowska A, Hochól A, Pucher A, Macchi C, Belloni AS, Nussdorfer GG and Malendowicz LK: Estradiol and resveratrol stimulating effect on osteocalcin, but not osteonectin and collagen- $1 \alpha$ gene expression in primary culture of rat calvarial osteoblast-like cells. Int J Mol Med 18: 565-570, 2006.

30. Ziolkowska A, Rucinski M, Tyczewska M, Belloni AS, Nowak M, Nussdorfer GG and Malendowicz LK: Downregulation of the beacon gene expression in the regenerating rat adrenal cortex. Peptides 27: 3216-3219, 2006

31. Ziolkowska A, Tortorella C, Nussdorfer GG, Rucinski M, Majchrzak M and Malendowicz LK: Accumulation of steroidogenic acute regulatory protein mRNA and decrease in the secretory and proliferative activity of rat adrenocortical cells in the presence of proteasome inhibitors. Int J Mol Med 17: 865-868, 2006.

32. Domin J, Ghatei MA, Chohan P and Bloom SR: Characterization of neuromedin U like immunoreactivity in rat, porcine, guineapig and human tissue extracts using a specific radioimmunoassay. Biochem Biophys Res Commun 140: 1127-1134, 1986.

33. Domin J, Ghatei MA, Chohan P and Bloom SR: Neuromedin U: a study of its distribution in the rat. Peptides 8: 779-784, 1987.

34. Honzawa M, Sudoh T, Minamino N, Tohyama M and Matsuo H: Topographic localization of neuromedin U-like structures in the rat brain: an immunohistochemical study. Neuroscience 23: 1103-1122, 1987

35. Ballesta J, Carlei F, Bishop AE, Steel JH, Gibson SJ, Fahey M, Hennessey R, Domin J, Bloom SR and Polak JM: Occurrence and developmental pattern of neuromedin U-immunoreactive nerves in the gastrointestinal tract and brain of the rat. Neuroscience 3: 797-816, 1988.

36. Steel JH, Van Noorden S, Ballesta J, Gibson SJ, Ghatei MA, Burrin J, Leonhardt U, Domin J, Bloom SR and Polak JM: Localization of $7 \mathrm{~B} 2$, neuromedin $\mathrm{B}$, and neuromedin $\mathrm{U}$ in specific cell types of rat, mouse, and human pituitary, in rat hypothalamus and in 30 human pituitary and extrapituitary tumors. Endocrinology 122: 270-282, 1988.

37. Domin J, Al-Madani AM, Desperbasques M, Bishop AE, Polak JM and Bloom SR: Neuromedin U-like immunoreactivity in the thyroid gland of the rat. Cell Tissue Res 260: 131-135, 1990.

38. Ahren B: Regulatory peptides in the thyroid gland: a review on their localization and function. Acta Endocrinol 124: 225-232, 1991.

39. Cimini V, Van Noorden S, Timson CM and Polak JM: Modulation of galanin and neuromedin U-like immunoreactivity in rat corticotropes after alteration of endocrine status. Cell Tissue Res 272: 137-146, 1993.

40. Ivanov TR, Lawrence CB, Stanley PJ and Luckman SM Evaluation of neuromedin $U$ actions in energy homeostasis and pituitary function. Endocrinology 143: 3813-3821, 2002.

41. Brighton PJ, Szekeres PG and Willars GB: Neuromedin U and its receptors: structure, function, and physiological roles. Pharmacol Rev 56: 231-248, 2004.

42. Brighton PJ, Szekeres PG, Wise A and Willars GB: Signaling and ligand binding by recombinant neuromedin $U$ receptors: evidence for dual coupling to Galphaq/11 and Galphai and an irreversible ligand-receptor interaction. Mol Pharmacol 66: 1544-1556, 2004.

43. Raddatz R, Wilson AE, Artymyshyn R, Bonini JA, Borowsky B, Boteju LW, Zhou SQ, Kouranova EV, Nagorny R, Guevarra MS, Dai M, Lerman GS, Vaysse PJ, Branchek TA, Gerald C, Forray C and Adham N: Identification and characterization of two neuromedin $U$ receptors differentially expressed in peripheral tissues and the central nervous system. J Biol Chem 275: 32452-32459, 2000 .

44. Graham ES, Turnbull Y, Fotheringham P, Nilaweera K, Mercer JG, Morgan PJ and Barrett P: Neuromedin U and neuromedin $U$ receptor- 2 expression in the mouse and rat hypothalamus: effects of nutritional status. J Neurochem 87: 1165-1173, 2003.

45. Shan LX, Qiao XD, Crona JH, Behan J, Wang S, Laz T, Bayne M, Gustafson EL, Monsma FJ and Hedrick JA: Identification of a novel neuromedin $U$ receptor subtype expressed in the central nervous system. J Biol Chem 275: 39482-39486, 2000. 
46. Westfall TD, McCafferty GP, Pullen M, Gruver S, Sulpizio AC, Aiyar VN, Disa J, Contino LC, Mannan IJ and Hieble JP: Characterisation of neuromedin U effects in canine smoothmuscle. J Pharmacol Exp Ther 301: 987-992, 2001.

47. Hosoya M, Moriya T, Kawamata Y, Ohkubo S, Fujii R, Matsui H, Shintani Y, Fukusumi S, Habata Y, Hinuma S, Onda H, Nishimura $\mathrm{O}$ and Fujino $\mathrm{M}$ : Identification and functional characterization of a novel subtype of neuromedin U receptor. J Biol Chem 275: 29528-29532, 2000.
48. Shousha S, Nakahara K, Sato M, Mori K, Miyazato M, Kangawa K and Murakami N: Effect of neuromedin S on feeding regulation in the Japanese quail. Neurosci Lett 391: 87-90, 2006.

49. Vigo E, Roa J, Lopez M, Castellano JM, Fernandez-Fernandez R, Navarro VM, Pineda R, Aguilar E, Dieguez C, Pinilla L and Tena-Sempere M: Neuromedin $S$ as novel putative regulator of luteinizing hormone secretion. Endocrinology 148: 813-823, 2007. 